\title{
Sex, Friends and Bullying Among Adolescents
}

\author{
Erni Gustina, Marsiana Wibowo \\ Department of Public Health, Ahmad Dahlan University, Yogyakarta, Indonesia
}

\begin{tabular}{l} 
Article Info \\
\hline Article history: \\
Received Jun 29, 2015 \\
Revised Aug 20, 2015 \\
Accepted Aug 22, 2015 \\
\hline
\end{tabular}

\section{Keyword:}

Adolescents

Bullying

Friends

Sex

\begin{abstract}
Bullying is a common problem among adolescents in the world. Bullying gives serious long-term effects on mental and physical health. Several studies found that adolescent involvement in bullying was related with maladjustment for both male and female. Male are more involved in physical and verbal bullying, whereas girls are more involved in relational bullying. Having a lot of friends can protect adolescents from bullying behavior and reduce their vulnerability to be a bullying victim. The purpose of this study was to know the relationship between sex and the number of friends with bullying among adolescents in Junior high School at Yogyakarta city. This study was an observational analytic study with cross sectional design. The samples of the study were adolescent aged 13-15 years in five junior high schools. The instrument of the study was a questionnaire. Data were analyzed using chi square test. There were 250 adolescent involved in the study. The highest bullying incidence was $77.27 \%$ and the lowest was $22.73 \%$. Both of them were verbal bullying. Bivariat analysis showed relationship was between sex and bullying $(\mathrm{p}=0.03 ; \mathrm{PR}=0.74)$ and there was no relationship between the number of friends and bullying $(\mathrm{p}=0.23 ; \mathrm{PR}=1.26)$. It can be concluded that there was relationship between sex and bullying among adolescents but there was no relationship between number of friends and bullying among adolescents. School should concern strict rules againt bullying behavior to minimize the occurrence of bullying behavior at school.
\end{abstract}

Copyright (C) 2015 Institute of Advanced Engineering and Science. All rights reserved.

\section{Corresponding Author:}

Erni Gustina,

Faculty of Public Health,

Universitas Ahmad Dahlan,

J1. Prof. Dr Soepomo Janturan Yogyakarta 55164, Indonesia.

Email: erni.gustina@ikm.uad.ac.id

\section{INTRODUCTION}

Bullying is an aggressive behavior type of proactive form containing there aspects of intent to dominate, hurt, or get rid of, an imbalance of power, and done repeatedly by one or several adolescents against another adolescents both psychologically, verbally or physically [1]-[3]. There are many types of bullying: spreading rumors and saying bad things, taking the belongings of others and victims of physical violence, excluding from social interaction [4].

The worldwide prevalence of bullying varies from $9 \%$ to $54 \%$ among adolescents. Adolescents who reported intimidate others and intimidated by others (bully-victim) approximately 4-6\% [5]-[6]. As many as $10-20 \%$ of children and adolescents are often involved in bullying, either as bullies, victims or both, and boys are often more involved than girls. Younger adolescents are more likely to be the victims than older adolescents [7]. Study shows that out of 378 students as subject, 53.2\% were never intimidate, $46.8 \%$ of children showed they had been bullied during the school day, $22.8 \%$ to be bothered as much as 2 times and $24.1 \%$ three times or more. As many as $20.1 \%$ of boys reported being bullied as much as five times or more and $8.2 \%$ for adolescent girls. Boys are more involved in physical and verbal bullying, whereas girls are 
more involved in relational bullying [8]. Of the 106 cases, $28.6 \%$ of adolescent are victims of physical aggression (punches and kicks), whereas 76 (20.5\%) are victims of theft [9].

Bullying provides an impact on the lives of the children and their life is reflected in adulthood [10]. Studies have found an association between involvement in bullying and maladjustment of both boys and girls. In adolescent girls, there was a strong correlation between bullying victims and suicide, while adolescent boys who are victims of bullying strongly were associated with psychosocial adjustment problems [7]. Individual factors such as personality also has an important role in bullying, such as shyness, lack of self-control, seniority, and the experience of bullying in the past [11]. Having a lot of friends will be negatively related to violence either be bullies, victims or bully-victim. Adolescents who became bullies tend to be socially isolated [8].

Bullying in the lives of children and adolescents can contribute to the development of physical and emotional problems, especially stress and the risk of decreased self-esteem, anxiety and depression, unhappiness and in more severe cases lead to suicide [12]. Studies suggest that bullies spend more time at home without adult supervision. Bullies are also in a higher level of risk to be involved in crime, alcohol abuse, smoking, cheating during exams, bringing weapons to school and delinquency, while the victims were in a higher level of risk for experiencing depression and low self-esteem in adulthood [3],[10]. The purpose of this study was to know the relationship between sex and the number of friends with bullying among adolescents in Junior high School at Yogyakarta city.

\section{RESEARCH METHOD}

This study was observational analytic study using cross sectional study design. Sample this study were 250 adolescents aged 13-15 years in five junior high schools at Yogyakarta city. The sampling technique used simple random sampling. The data used in this study were primary data taken directly from the research subjects. The instrument used in this study was a questionnaire. Data analysis included univariate, bivariate used Chi-Square test. Univariate analysis employed to explain or describe the characteristics of each variable. Bivariate analysis was conducted to determine the relationship between sex, number of friends and bullying.

\section{RESULTS AND ANALYSIS}

\subsection{Descriptive Analysis}

Results of univariate analysis are shown in Table 1 . Table 1 shows that based on sex mostly were males in the amount of $126(50.4 \%)$. Based on the number of friends there were adolescents who have friends more than three were $220(88 \%)$. Based on the status of bullying found a subject that often experienced were $116(46.4 \%)$.

Tabel 1. Frequency distribution of sex, number of friends and bullying

\begin{tabular}{lcc}
\hline \multicolumn{1}{c}{ Variable } & Amount & Presentage (\%) \\
\hline Sex & & \\
$\quad$ Female & 124 & 49.6 \\
$\quad$ Male & 126 & 50.4 \\
$\begin{array}{l}\text { Number of friends } \\
<3\end{array}$ & 30 & 12 \\
$\quad \geq 3$ & 220 & 88 \\
Bullying & & \\
$\quad$ Often & 116 & 46.4 \\
$\quad$ Rarely & 134 & 53.6 \\
\hline
\end{tabular}

Table 2 shows that bullying happened in all schools studied by this research with various percentages. The highest incidence of bullying at school was as much as $77.27 \%$ and the lowest was $22.73 \%$ 
Tabel 2. Bullying frequency distribution at schools based on item bullying

\begin{tabular}{|c|c|c|c|c|c|c|c|c|c|c|c|c|}
\hline \multirow{4}{*}{$\begin{array}{l}\text { School } \\
\text { Code } \\
\text { A }\end{array}$} & \multicolumn{12}{|c|}{ Item bullying } \\
\hline & \multicolumn{4}{|c|}{ Physic } & \multicolumn{4}{|c|}{ Verbal } & \multicolumn{4}{|c|}{ Social } \\
\hline & \multicolumn{2}{|c|}{ Often } & \multicolumn{2}{|c|}{ Rarely } & \multicolumn{2}{|c|}{ Often } & \multicolumn{2}{|c|}{ Rarely } & \multicolumn{2}{|c|}{ Often } & \multicolumn{2}{|c|}{ Rarely } \\
\hline & 27 & 45.76 & 32 & 54.24 & 23 & 38.98 & 36 & 61.02 & 15 & 25.42 & 44 & 74.58 \\
\hline B & 27 & 57.45 & 20 & 42.55 & 25 & 53.19 & 22 & 46.81 & 26 & 55.32 & 21 & 44.68 \\
\hline $\mathrm{C}$ & 15 & 68.18 & 7 & 31.82 & 17 & 77.27 & 5 & 22.73 & 15 & 68.18 & 7 & 31.82 \\
\hline D & 21 & 32.31 & 44 & 67.69 & 20 & 30.77 & 45 & 69.23 & 25 & 38.46 & 40 & 61.54 \\
\hline E & 33 & 57.89 & 24 & 42.11 & 31 & 54.39 & 26 & 45.61 & 25 & 43.86 & 32 & 56.54 \\
\hline
\end{tabular}

\subsection{Bivariate Analysis}

Bivariate analysis aims to determine the relationship between sex, number of friend and bullying. The statistical test employed Chi-square test. The results of the test presented in Table 3.

Tabel 3. The relationship between sex, number of friend and bullying among adolescents

\begin{tabular}{|c|c|c|c|c|c|c|c|}
\hline \multirow[t]{2}{*}{ Variable } & \multicolumn{4}{|c|}{ Bullying } & \multirow[t]{2}{*}{$p$} & \multirow[t]{2}{*}{$\mathrm{RP}$} & \multirow[t]{2}{*}{ CI95\% } \\
\hline & & Often & & ely & & & \\
\hline \multicolumn{8}{|l|}{ Sex } \\
\hline Female & 49 & 39.52 & 75 & 60.48 & 0.03 & 0.74 & $0.56-0.98$ \\
\hline Male & 67 & 53.17 & 59 & 46.83 & & & \\
\hline \multicolumn{8}{|c|}{ Number of Friends } \\
\hline$<3$ & 17 & 56.67 & 13 & 43.33 & 0.23 & 1.26 & $0.89-1.78$ \\
\hline$\geq 3$ & 99 & 45.00 & 121 & 55.00 & & & \\
\hline
\end{tabular}

Table 3 shows that there was relationship between sex and bullying $(p=0.03)$, but there was no relationship between number of friends and bullying $(\mathrm{p}=0.23)$.

\section{DISCUSSION}

Based on the results of univariate analysis, of 250 respondents there were 116 (46.4\%) students who often became victims of bullying. Research showed than 378 adolescents, $46.8 \%$ of adolescents have been bullied during the school day, $22.8 \%$ hassled as much as two times and $24.1 \%$ bullied three times or more [8]. The prevalence of bullying behavior among school-aged was $53.4 \%$. The prevalence of bullying behavior was varies, $17.7 \%$ as bullies, $19.8 \%$ as victims, and $15.8 \%$ as bully-victims. Verbal intimidation $(12.48 \%)$, including spreading rumors $(12.2 \%)$, was the most common type of victims, followed by a rejected from group (10.4\%) [13]. Based on a study of 1,230 school showed the prevalence of victims and perpetrators of bullying was $10.2 \%$ and $7.1 \%$ [14].

From of the 250 respondent, it could observe that $126(50.4 \%)$ respondents were male students. Table 3 showed there was relationship sex with a victim of bullying $(\mathrm{p}=0.03$; $\mathrm{PR}=0.74,95 \% \mathrm{CI}=0.56-$ 0.98). Boys were found involved in bullying as bullies and victims more often than female adolescents. Boys more often involved as bullies or victims in physically aggressive behavior. In contrast, girls are more likely to engage in verbal and relational aggression as bullies or victims [15]-[18].

Based on the results of the bivariate analysis, it can be found that there was no relationship between the number of friends and bullying $(\mathrm{p}=0.23$ : $\mathrm{PR}=1.26: 95 \% \mathrm{CI}=0.89-1.78)$. This can occur because there are more students having friends than three than the students having friends less than three. It means that having friends in large numbers can protect students from bullying.

Friendship quality can contribute to reduce adolescent to be victims of bullying. Friendship can protect adolescents from bullying behavior and improve their psychosocial adjustment, so it can reduce their vulnerability to become victims of bullying. Friends who act as advocates on adolescents who bullied can provide both emotional and instrumental support. Friends who act as advocates not only serve to provide comfort and support to victims of bullying, but also to prevent acts of intimidation not to occur [19].

The quality and quantity of friendship can protect teens not to become a victim. Have a lot of friends who can give a positive value so that teens have social skills and require teens to think of others. On the other hand antisocial adolescents exhibit aggressive behavior towards others [19]. 


\section{CONCLUSION}

There was relationship between sex and bullying, but there was no relationship between the number of friends and bullying. To reduce the incidence of bullying in schools there should be school-based intervention for students who experience bullying and they must report to the school to immediately get treatment from school, and courage to face all bullying. Schools should concern strict rules against bullying behavior to minimize the occurrence of bullying behavior in school.

\section{ACKNOWLEDGEMENTS}

The author would like to thank the principals and junior high school students in Yogyakarta who were involved in this study.

\section{REFERENCES}

[1] Olweus, D., "Bullying at school: What we know and what we can do",Oxford: Blackwell, 1993.

[2] Nansel, T. R., Overpeck, M., Pilla, R. S., Ruan, W. J., Simons-Morton, B., Scheidt, P., "Bullying behaviors among US youth: Prevalence and association with psychosocial adjustment”, JAMA, vol/issue: 285(16), pp. 2094-2100, 2001.

[3] Veenstra, R., Lindenberg, S., Oldehinkel, A. J., De Winter, A. F., Verhulst, F. C., Ormel, J., "Bullying and victimization in elementary schools: A comparison of bullies, victims, bully/victims, and uninvolved preadolescents", Developmental Psychology, vol/issue: 41(4), pp. 672-82, 2005.

[4] Fekkes, M., Pijpers F. I., Verloove-Vanhorick S. P., "Bullying: who does what, when and where? Involvement of children, teachers and parents in bullying behavior", Health Educ Res, vol. 20, pp. 81-91, 2005.

[5] Haynie, D. L., Nansel T., Eitel P., Crump A. D., Saylor K., Yu K., Simons-Morton B., "Bullies, victims, and bully/victims: Distinct groups of at-risk youth", J Early Adolesc, vol/issue: 21(1), pp. 9-49, 2001.

[6] Nansel, T. R., Craig, W., Overpeck, M. D., Saluja, G., Ruan, W. J., "Cross-national consistency in the relationship between bullying behaviors and psychosocial adjustment", Arch Pediatr Adolesc Med, vol/issue: 158(8), pp.730-6, 2004.

[7] Kaltiala-Heino, R., Frojd S., Marttunen M., "Involvement in bullying and depression in a 2-year follow-up in middle adolescence”, Eur Child Adolesc Psychiatry, vol. 19, pp. 45-55, 2010.

[8] Silva M. A. I., Pereira B., Mendonça D., Nunes B., de Oliveira WA., "The Involvement of Girls and Boys with Bullying: An Analysis of Gender Differences", Int. J. Environ. Res. Public Health, vol. 10, pp. 6820-6831, 2013.

[9] Wang, J., Iannotti, R. J., Nansel, T. R., "School bullying among adolescents in the United States: Physical, verbal, relational, and cyber", Journal of Adolescent Health, vol. 45, pp. 368-375, 2009.

[10] Pereira, B., Mendonça D., Neto C., Valente L., Smith P. K., "Bullying in Portuguese schools", Sch. Psychol. Int, vol. 25, pp. 207-222, 2004.

[11] Ahmed, E., Braithwaite, V., "Bullying and victimization: Cause for concern for both families and school", Sosial Psychology of Education, vol.7, pp. 35-54, 2004.

[12] Jankauskiene, R., Kardelis K., Sukys S., Kardeliene L., "Associations between school bullying and psychosocial factors", Soc. Behav. Personal, vol. 36, pp. 145-162, 2008.

[13] Khamis, V., "Bullying among school-age children in the greater Beirut area: Risk and protective factors", Child Abuse \& Neglect, vol. 39, pp. 137-146, 2015.

[14] Rech, R. R., Halpern R., Tedesco A., Santos D. F., "Prevalence and characteristics of victims and perpetrators of bullying", J Pediatr, vol/issue: 89(2), pp. 164-170, 2013.

[15] Lee, E., "The relationship of aggression and bullying to social preference: differences in gender and types of aggression”, International Journal of Behavioral Development, vol/issue: 33(4), pp. 323-330, 2009.

[16] Wissink, I. B., Dekovic M., Meijer A. M., "Adolescent friendship relations and developmental outcomes: ethnic and gender differences", The Journal of Early Adolescence, vol/issue: 29(3), pp. 405-425, 2009.

[17] Carbone-Lopez, K., Esbensen F. A., Brick B. T., "Correlates and consequences of peer victimization: gender differences in direct and indirect forms of bullying", Youth Violence and Juvenile Justice, vol/issue: 8(4), pp.332$350,2010$.

[18] Dukes, R. L., Stein J. A., Zane J. I., "Gender differences in the relative impact of physical and relational bullying on adolescent injury and weapon carrying", Journal of School Psychology, vol. 48, pp. 511-532, 2010.

[19] Kendrick, K., Jutengren G., Stattin H., "The protective role of supportive friends against bullying perpetration and victimization", Journal of Adolescence, vol. 35, pp. 1069-1080, 2012. 